\title{
Hotels
}

\section{The state of the European hotel spa sector}

Recerved: 21 April 2005

\section{Kristin Thorsteinsdottir}

is a research analyst at HVS International, specialists in hotel valuation and consultancy. She joined the company in September 2004 having completed an MSc in international hotel and tourism management at Oxford Brookes University.

\begin{abstract}
Spas have a long tradition in Europe, where they were traditionally visited to obtain medical benefits. In recent years hoteliers have realised the various benefits that a spa facility can bring in terms of hotel revenue. This has led to a significant increase in the opening of both hotel spas and destination spas, and a number of developments are still under way. But this remains a fragmented and unregulated sector where little is known about the overall performance of spa establishments. The European spa tradition faces ever harder competition from Asian-based spa companies which have acquired a strong foothold in the European hotel spa and destination spa market. The purpose of this paper is to shed light on recent developments and the issues facing the European spa hotel sector.
\end{abstract}

\section{Keywords:}

hotel spa, destination spa, ISPA, industry data, spa developments

Kristın Thorsteinsdottir HVS International 14 Hallam Street London, WiW 6JG, UK Tel: +44 (o) 2078787715 E-mail:

kthorsteinsdottir@hvsinternational.com

\section{INTRODUCTION}

Spa - the name of the Belgian town where the benefits of bathing in hot springs were first discovered - now embraces a variety of establishments and treatments that are increasingly becoming a standard feature at hotels and resorts. An interest in health and well-being, combined with an increase in disposable income, have resulted in strong demand for spas in recent years. A report recently commissioned by the US-based International SPA Association (ISPA) ${ }^{1}$ concludes that the spa industry has become a major player within the leisure and hospitality industry, keeping pace with, and even surpassing, other leisure activities in revenues and weathering the challenges of a weak economy.

As centres of healing, spas have been a part of European culture for centuries; however, it is only recently that the spa has taken off as a service offering within the hotel sector. While the evolution 
and volume of the spa industry are well documented in other parts of the world, such as the USA, less is known about the situation in Europe.

\section{WHAT IS IN A SPA?}

As mentioned earlier, the word spa now encompasses a range of establishments whose common goal is to enhance overall well-being through a variety of professional services that encourage the renewal of mind, body and spirit. ISPA has classified spas using seven categories, based on the services on offer as well as their location. In Europe, spa facilities and services often differ slightly from those outlined by ISPA, as summarised in Table $1 .^{2}$ For instance, European spas rarely carry an educational component, and there is no evidence suggesting that the medical spa sector is anywhere near as developed in Europe as it is in the USA.

While the focus of this paper is on spas that are operated in conjunction with or inside hotels, one should emphasise the differences between a destination spa and a hotel spa, which might not always be clear. While the spa operation is the core product of the destination spa, this is usually not the case in hotel spas where the spa is one of many amenities and where its usage is usually secondary to other leisure or business activities performed at the hotel. Additionally, there is usually a strong focus on special nutrition, exercise and relaxation in destination spas, whereas hotel spas are often simply aimed at providing a quick getaway from the stress of everyday life. Spa treatments in hotel spas usually consist of a variety of individual treatments that can be purchased separately, while a stay at a destination spa is often in the form of a complete package where the accommodation, meals and treatments are included. Finally, destination spas range from being basic establishments to luxurious resorts, while hotel spas are usually only found in four- and five-star hotels. ${ }^{3}$

\section{THE EVOLUTION OF SPA HOTELS IN EUROPE}

Spas have been frequented by Europeans for centuries. Traditional spa destinations such as Baden-Baden in Germany, Terme Abano in Italy and Karlovy Vary in the Czech Republic were founded on the health benefits obtained from naturally occurring resources, mainly water and mud. But an ageing population with increased disposable income has fuelled demand for a new generation of hotel- and resort-based spa facilities, changing the face of the industry over the past decade while becoming a major focus for leisure investment. The modern spa is unbound from natural resources, and appeals to a wider audience than the traditional spas. While spa visits were traditionally motivated by medical purposes, modern spas are aimed at a wider audience who visit a spa for beauty, relaxation and leisure purposes. This phenomenon has caused some concern among the traditional spas of Europe, which fear a diminishing of the value of the spa experience. 
Table I: ISPA and European definitions of spas

\begin{tabular}{|c|c|c|}
\hline & ISPA definition & European version \\
\hline Club spa & $\begin{array}{l}\text { A facility primarily used for } \\
\text { fitness purposes, offerıng a } \\
\text { varıety of professionally } \\
\text { admınıstered spa services on a } \\
\text { membership basıs. }\end{array}$ & $\begin{array}{l}\text { Similar establıshments, but not } \\
\text { common in Europe. }\end{array}$ \\
\hline Cruise ship spa & $\begin{array}{l}\text { Aboard a cruise ship providing } \\
\text { professionally administered } \\
\text { spa services, fitness and } \\
\text { wellness. Although mostly } \\
\text { outsourced to a third party, } \\
\text { some cruise companies are } \\
\text { creatıng their own brand and } \\
\text { operatıng spas themselves. }\end{array}$ & $\begin{array}{l}\text { Slightly different services } \\
\text { focusing primarily on beauty, } \\
\text { body treatments and fitness. }\end{array}$ \\
\hline Day spa & $\begin{array}{l}\text { A spa offering a variety of } \\
\text { professionally administered } \\
\text { spa services to clients on a } \\
\text { day-use basis }\end{array}$ & $\begin{array}{l}\text { Very sımılar establishments; } \\
\text { however, broader range of } \\
\text { establıshments from small } \\
\text { fitness-focused day spas to big } \\
\text { holistic or entertaining spas. }\end{array}$ \\
\hline Destınatıon spa & $\begin{array}{l}\text { An establishment where the } \\
\text { spa facilities and services are } \\
\text { the core of the product, often } \\
\text { combined with an educational } \\
\text { programme, healthy cuisine } \\
\text { and on-site accommodation. }\end{array}$ & $\begin{array}{l}\text { Similar establishments but very } \\
\text { rarely with an educational focus. } \\
\text { Mostly in the form of standalone } \\
\text { resorts located in } \\
\text { picturesque countryside or by } \\
\text { the seaside. }\end{array}$ \\
\hline Medical spa & $\begin{array}{l}\text { Institutions offering medical and } \\
\text { wellness care as well as spa } \\
\text { services. Often combined with } \\
\text { cosmetic surgery. }\end{array}$ & $\begin{array}{l}\text { A new creation of medical and } \\
\text { welibeing services, often } \\
\text { offered in hotels/resorts. Not } \\
\text { common in Europe. }\end{array}$ \\
\hline Mineral springs spa & $\begin{array}{l}\text { A spa offering an on-site source } \\
\text { of natural mineral, thermal or } \\
\text { seawater. Not common in the USA }\end{array}$ & $\begin{array}{l}\text { Traditional type of spa in Europe } \\
\text { located near springs and thermal } \\
\text { waters. Many sub-categories. }\end{array}$ \\
\hline Hotel spa & $\begin{array}{l}\text { A spa within a resort or hotel } \\
\text { providing professionally } \\
\text { admınıstered spa services, } \\
\text { fitness and wellness } \\
\text { components. Spa cuisıne } \\
\text { menu. Fastest growing } \\
\text { segment of the market and } \\
\text { increasingly an expected } \\
\text { component of a resort. Hotel } \\
\text { companies increasingly } \\
\text { developing own spa brands. }\end{array}$ & $\begin{array}{l}\text { Most common type of spa in } \\
\text { Europe. Great variations in size. } \\
\text { facilities and services. }\end{array}$ \\
\hline
\end{tabular}

No official data exist that describe the size and volume of the European spa industry. In the USA the spa industry remains the fourth-largest leisure industry, however, with a 25 per cent increase in the number of spas between 2002 and 2003, surpassing other traditional leisure industries such as theme parks. ${ }^{4}$ Generating 136 million visits in 2003 , the US spa sector has been doubling every four years to meet the rising demand for these facilities.

Furthermore, the ISPA report estimates that there are over 12,000 spas in the USA, with the largest category being day spas; resorts/ spa hotels comprise the second-largest and fastest-growing sector, followed by club spas and medical facilities. ${ }^{5}$ 
Spas in hotels have come a long way from being a rare luxury to being a near necessity, with hoteliers realising the various benefits that a spa facility can bring to a hotel. Not only does a wellplanned spa contribute directly to revenue and profitability, but it can also justify a premium on the average room rate and help to overcome seasonality issues. A recent survey carried out among over 50 luxury spa hotels across the world revealed that the average development cost per square metre was approximately $£ 1,800$, while the declared spa turnover was equivalent to $£ 400$ per square metre per annum. Assuming a net operating profit at a rate of 25 per cent, the average spa could generate a net operating profit in the region of $£ 100$ per square metre per annum, which is equal to an indicative return on investment in the region of 6 per cent, assuming an average capital cost of $£ 1,800$ per square metre. $^{6}$

\section{EXAMPLES OF CURRENT DEVELOPMENT ACTIVITY IN EUROPE}

While the traditional European spas mentioned earlier were indeed destinations in themselves, the main drive behind their visitation was to receive medical benefits and not the relaxation and wellbeing aspects that fuel most of the demand of modern spa visitors. On the other hand, spiritual well-being is equally important to physical well-being in Asian spas, and the industry is currently witnessing the invasion of Asian destination spa and hotel spa companies into Europe.

The Singapore-based hotel group Banyan Tree, which currently operates destination spas in Japan, China, Thailand, the Seychelles and Indonesia, has recently signed an agreement to open a spa resort in Greece. No further information was available on this development at the time of writing. Six Senses, another Asian company which develops and operates destination and hotel spas, recently opened its first European hotel spa in the Ritz-Carlton Hotel Arts in Barcelona. Other European projects that the company has in the pipeline include a spa at Elounda Hotels and Resorts, Crete, whose grand opening is set for summer 2006, and a spa in the Ritz-Carlton Penha Longa Resort near Estoril, Portugal, whose doors are to open in July 2005. The company will also operate a spa in the Kempinski Barbados Bay Residences in Bodrum, Turkey, which is opening in June 2005. Finally, Six Senses will operate a spa in the Mount Juliet Conrad International in Kilkenny, Ireland, whose opening is planned for late 2005.

A third Asian company, Raffles Hotels and Resorts, already operates five hotel spas in Europe and will soon be expanding its own-brand 'Amrita Spa' into Eastern Europe when the Swissôtel Krasnye Holmy opens in Moscow in July 2005. The Raffles Resort planned at Colinas d'Es Trenc in Mallorca will also include a new Amrita Spa. Mandarin Oriental Hotels, which currently has hotel spas in its properties in London and Paris, will be adding a third hotel spa when its Prague property opens in early 2006. Mandarin 
Oriental's London spa was developed in association with E'SPA, a UK spa development and consulting company, as was the spa opening in the Palace Luzern Hotel in Switzerland in July 2005. Also opening in July 2005 is a new $3,437 \mathrm{~m}^{2}$ spa and health club at the Heritage Hotel in Killenard, County Laois, in Ireland. Finally, it recently emerged that one of the traditional European medical spas, the Rác Bath in Budapest, will be completely restored and reopened in September 2006 under the Kempinski flag, which will be adding a 55-room hotel to the site.

\section{ISSUES FACING THE EUROPEAN SPA HOTEL SECTOR}

From the examples above it becomes clear that development and renovation activity is lively and European destination and hotel spas are becoming increasingly subject to branding. Nevertheless, the spa hotel sector in Europe remains fragmented and unregulated. As yet, rules and regulations governing spa operations and standards are lacking. The Spa Business Association in the UK has drawn attention to the fact that, with health-related tourism steadily increasing and spas attracting considerable interest from banks and investors, spa industry regulation and presentation is a necessity if European spas are to increase market share and maintain the integrity of their spa facilities and services. Similarly, the European Spa Association recently concluded that there is a need for coordinated structures and instruments that lead to more transparency in the market. In order to achieve that, the association proposed the adoption of certificates according to ISO 9000/2000 standards as well as a ranking system to make the classification of the various types of spa that exist achievable.

Another challenge facing the industry in terms of future investment is the lack of trustworthy industry facts and performance data, not only for potential investors and developers but also in order for spa owners and operators to be able to benchmark their spas against other players in the industry. It has been suggested that two major challenges have to be overcome in order for such data to be produced. ${ }^{7}$ First, there is a lack of standard management tools that can be used to collect and compare benchmark data, and secondly, there has never existed a uniform system of accounting for spas, although such a system is currently under development as an initiative of the International Spa Association.

\section{CONCLUSION}

It is clear that despite a long spa tradition it is only now that the combination of spa and hotel has taken off in Europe, and current development activity confirms that the industry is soon to witness an influx of new establishments. In order to assess the performance of this sector it is essential that more research and industry data become available, as is the case in the USA. It will, however, be a challenge to produce accurate benchmarks as the sector remains 
fragmented and difficult to classify. The European spa tradition faces ever harder competition from Asian-based companies, whose spa tradition is more in line with the needs of the modern spa consumer. In order for the European spa hotel sector to retain its integrity and market share, it is essential that a framework for regulation and classification is developed.

\section{ACKNOWLEDGMENT}

The author would like to thank Patty Monteson and Judy Singer from Health Fitness Dynamics, Inc. for their permission to include their material in this paper.

\section{References}

1. International SPA Association (2004) 2004 Spa Industry Study, ISPA, Lexington, KY.

2. Monteson, $\mathbf{P}$ and Singer, J. (2005) Conference proceedings, distributed at the Spa Development and Operations Conference by HFD/4 Spa Ladies, Berlın, Germany, 15 16 March.

3. Ibid.

4. International SPA Association, ref. 1 above.

5. Ibld.

6. Camble, P. (2005) 'Are spas worth 1t?. Luxury Horlzons, February.

7 Singer, J. L. (2004) 'Is your spa a lazy asset?', National Hotel Executive, 11 August. 